И. Ю. Унгаева, Н. Э. Шабыкова. Формирование региональной промышленной инфраструктуры как фактор развития производственного предпринимательства

Научная статья

УДК 338.49

DOI: $10.18101 / 2304-4446-2021-2-83-89$

\title{
ФОРМИРОВАНИЕ РЕГИОНАЛЬНОЙ ПРОМЫШЛЕННОЙ ИНФРАСТРУКТУРЫ КАК ФАКТОР РАЗВИТИЯ ПРОИЗВОДСТВЕННОГО ПРЕДПРИНИМАТЕЛЬСТВА
}

\author{
(C) Унгаева Инна Юрьевна \\ кандидат экономических наук, доцент \\ inna120175@mail.ru \\ (C) Шабыкова Наталья Эдуардовна \\ кандидат экономических наук, доцент \\ shab-natalya@list.ru
}

Восточно-Сибирский государственный университет технологий и управления Россия, 670013, г. Улан-Удэ, ул. Ключевская, 40в

\begin{abstract}
Аннотация. Формирование развитой промышленной инфраструктуры, к которым относятся промышленные парки и технопарки, является актуальной задачей региональной промышленной политики. В статье рассматриваются направления по созданию технопарков и промышленных парков. Рассмотрен опыт становления технопарков при высших учебных заведениях в Российской Федерации как научнотехнологической базы реализации инновационных проектов. На основе анализа действующего законодательства для создания технопарков различными государственными органами власти представлены виды технопарков в Российской Федерации. Рассмотрены направления государственного развития и модели формирования технопарков: инновационная, университетская и производственная. Исследованы отличительные особенности промышленных парков и технопарков. Представлены меры государственной поддержки создания технопарков и их роль в развитии региональной экономики. Проведен анализ наличия и потребности промышленной инфраструктуры для нужд малого бизнеса Республики Бурятия.

Ключевые слова: промышленный парк, технопарк, промышленная инфраструктура, управляющая компания, резидент технопарка, малое предпринимательство, малый бизнес, региональная промышленная политика
\end{abstract}

\section{Для цитирования}

Унгаева И. Ю., Шабыкова Н. Э. Формирование региональной промышленной инфраструктуры как фактор развития производственного предпринимательства // Вестник Бурятского государственного университета. Экономика и менеджмент. 2021. № 2. C. 83-89.

Создание новых промышленных производств в регионах, высокотехнологичных рабочих мест в реальном секторе экономики предполагает формирование современной промышленной инфраструктуры. Решению этой важнейшей задачи способствует формирование в регионах Российской Федерации индустриальных парков и промышленных технопарков. Федеральным законом от 31.12 .2014 г. № 488-Ф3 «О промышленной политике в Российской Федерации» определены 
инструменты территориального развития промышленности, к которым относятся индустриальные (промышленные) парки и промышленные технопарки ${ }^{1}$.

Следует отметить, что в Российской Федерации технопарки как научная, технологическая и техническая база для реализации инновационных проектов возникли еще в 1990-е гг. на базе ведущих университетов, а затем в научных центрах и наукоградах. Первый технопарк в нашей стране - «Томский научнотехнологический парк» - был создан совместно с Томским государственным университетом в 1990 г. В последующие годы создание университетских технопарков ускорилось: в 1991 г. стало 8 технопарков, в 1992 г. - 24, 1993 г. - 43. Однако этот период появления технопарков можно охарактеризовать стихийным, без соответствующей государственной стратегии и нормативной базы по данному вопросу. Первые технопарки, как правило, создавались как структурные подразделения вузов с целью коммерциализации научных разработок, кооперации науки и производства. Только в 2008 г. в связи с принятием Концепции долгосрочного социально-экономического развития Российской Федерации на период до 2020 г. на государственном уровне были сформулированы задачи развития технопарков и промышленных парков как инфраструктуры поддержки новых предприятий ${ }^{2}$.

На государственном уровне четыре федеральных ведомства занимались развитием технопарков в различных сферах деятельности:

1. Технопарки в сфере высоких технологий. Минкомсвязи РФ в соответствии с комплексной программой «Создание в Российской Федерации технопарков в сфере высоких технологий» создано и развивается 12 таких технопарков, в ведущих инновационных центрах страны, создавших в общей сложности десятки тысяч высокопроизводительных рабочих мест ${ }^{3}$. Программа была реализована в период с 2007 по 2014 г. и в настоящее время завершена.

2. Технопарки при высших учебных заведениях. Миннауки РФ предоставлялась государственная поддержка вузам с целью создания университетских технопарков, бизнес-инкубаторов, инновационно-технологических центров и других объектов инфраструктуры поддержки инноваций ${ }^{4}$. Данная программа также завершена. За период ее реализации создано 30 технопарков при высших учебных заведениях.

3. Технопарки и промышленные парки. Минэкономразвития РФ в рамках государственной программы РФ «Экономическое развитие и инновационная экономика» оказывает государственную поддержку регионам с целью обеспече-

1 О промышленной политике в Российской Федерации: федеральный закон от 31.12.2014 г. № 488-Ф3

${ }^{2}$ О Концепции долгосрочного социально-экономического развития Российской Федерации на период до 2020 г.: распоряжение Правительства Российской Федерации от 17.11.2008 г. № 1662-p

${ }^{3}$ О Комплексной программе «Создание в Российской Федерации технопарков в сфере высоких технологий»: распоряжение Правительства Российской Федерации от 10.03.2006 г. № 328-p.

${ }^{4} \mathrm{O}$ государственной поддержке развития инновационной инфраструктуры в федеральных образовательных учреждениях высшего профессионального образования: постановление Правительства Российской Федерации от 09.04.2010 г. № 219. 
И. Ю. Унгаева, Н. Э. Шабыкова. Формирование региональной промышленной инфраструктуры как фактор развития производственного предпринимательства

ние льготного доступа субъектов малого и среднего предпринимательства к производственным площадям и помещениям путем создания в субъектах РФ технопарков и промышленных парков. В регионах страны функционирует 176 промышленных парков ${ }^{1}$.

4. Промышленные технопарки. Минпромторгом РФ в соответствии с Федеральным законом от 31.12.2014 г. № 488-Ф3 «О промышленной политике в Российской Федерации» реализуется механизм государственного стимулирования создания промышленных технопарков. В настоящее время создано и действует 65 промышленных технопарков.

Таким образом, в настоящее время разработана нормативная база и определена государственная политика развития промышленной и инновационной инфраструктуры в виде технопарков и промышленных парков. Вышеизложенное позволяет выделить три модели создания и функционирования технопарков и промышленных парков.

Инновационная модель технопарков. Они создаются на базе крупных научноисследовательских центров, имеющих уникальную технологическую инфраструктуру для разработки и коммерциализации НИОКР. Такие технопарки создаются с целью акселерации малых и средних технологических компаний. Яркими примерами такой модели технопарков являются технопарк «Академпарк» (Новосибирск), «Физтехпарк» (Москва), технополис «Химград» (Казань) и другие.

Университетская модель технопарков. Такие технопарки создаются как структурные подразделения вузов с целью развития предпринимательских компетенций у ученых и студентов, коммерциализации разработок ученых. Университетские технопарки являются, как правило, государственными и не ставят целью получение прибыли, но могут оказывать технологические услуги сторонним организациям. Примерами таких технопарков являются технопарк «Научный парк МГУ» (Москва), «Технопарк ИРНИТУ» (Иркутск), «ТехноградПетрГУ» (Петрозаводск).

Производственная модель технопарков и промышленных парков. Такие технопарки создаются на базе крупных промышленных предприятий, имеющих свободные площади (браунфилд), или на новых свободных участках (гринфилд) с целью локализации промышленных производств. Примерами таких объектов промышленной инфраструктуры в Республике Бурятия являются промышленный парк, построенный на базе бывшего авиаремонтного завода, и промышленный технопарк «Аполлон» на базе свободных производственных мощностей Тимлюйского шиферного завода. Оба объекта относятся к типу браунфилд.

Рассмотрим отличительные особенности формирования технопарков и промышленных парков, механизмы государственной поддержки таких структур, а также их роль в развитии региональной промышленности. На основе исследования нормативной правовой базы нами в таблице 1 представлены сравнительные характеристики технопарков и промышленных парков.

\footnotetext{
1 Экономическое развитие и инновационная экономика: постановление Правительства Российской Федерации от 15.04.2014 г. № 316 «Об утверждении государственной программы Российской Федерации».
} 
Таблица 1

Сравнительные характеристики объектов промышленной инфраструктуры

\begin{tabular}{|c|c|c|}
\hline & Промышленный технопарк & $\begin{array}{c}\text { Индустриальный } \\
\text { (промышленный) парк }\end{array}$ \\
\hline Определение & $\begin{array}{l}\text { Технопарк, предназначенный для } \\
\text { осуществления субъектами мало- } \\
\text { го и среднего предприниматель- } \\
\text { ства промышленного производ- } \\
\text { ства, научно-технической дея- } \\
\text { тельности, инновационной дея- } \\
\text { тельности в целях освоения про- } \\
\text { мышленного производства про- } \\
\text { мышленной продукции и ком- } \\
\text { мерциализации научно- } \\
\text { технических результатов и управ- } \\
\text { ляемый управляющей компанией }\end{array}$ & $\begin{array}{l}\text { Совокупность объектов промыш- } \\
\text { ленной инфраструктуры (земель- } \\
\text { ные участки, административные, } \\
\text { производственные, складские и } \\
\text { иные помещения и объекты тех- } \\
\text { нической, транспортной и ком- } \\
\text { мунальной инфраструктуры), } \\
\text { обеспечивающих деятельность } \\
\text { парка и предназначенных для } \\
\text { предоставления условий для ра- } \\
\text { боты субъектов малого и средне- } \\
\text { го предпринимательства и осу- } \\
\text { ществления промышленного } \\
\text { производства, управляемых } \\
\text { управляющей компанией }\end{array}$ \\
\hline Назначение & $\begin{array}{l}\text { Готовые здания и площади офис- } \\
\text { ного, лабораторного и производ- } \\
\text { ственного назначения, оснащен- } \\
\text { ные производственным и техно- } \\
\text { логическим оборудованием }\end{array}$ & $\begin{array}{l}\text { Земельный участок с подведен- } \\
\text { ными коммуникациями и необо- } \\
\text { рудованные здания общепроиз- } \\
\text { водственного назначения }\end{array}$ \\
\hline $\begin{array}{l}\text { Площадь зе- } \\
\text { мельного участ- } \\
\text { ка, га }\end{array}$ & от 1,5 & от 8 \\
\hline $\begin{array}{l}\text { Площадь зда- } \\
\text { ний, м² }\end{array}$ & от 5000 & от 20000 \\
\hline $\begin{array}{l}\text { Виды деятель- } \\
\text { ности резиден- } \\
\text { тов }\end{array}$ & $\begin{array}{l}\text { Производство промышленной } \\
\text { продукции, оказание специали- } \\
\text { зированных услуг, исследования } \\
\text { и разработки }\end{array}$ & $\begin{array}{l}\text { Производство промышленной } \\
\text { продукции }\end{array}$ \\
\hline $\begin{array}{l}\text { Виды инфра- } \\
\text { структуры }\end{array}$ & $\begin{array}{l}\text { Коммунальная, транспортная и } \\
\text { технологическая }\end{array}$ & Коммунальная и транспортная \\
\hline $\begin{array}{l}\text { Требования к } \\
\text { коммунальной } \\
\text { инфраструктуре }\end{array}$ & $\begin{array}{l}\text { Электрическая энергия (мощ- } \\
\text { ность не менее } 1 \text { МВт), подклю- } \\
\text { чение к сетям газо- или тепло- } \\
\text { снабжения, водоснабжения, во- } \\
\text { доотведения }\end{array}$ & $\begin{array}{l}\text { Электрическая энергия (мощ- } \\
\text { ность не менее } 2 \text { МВт), подклю- } \\
\text { чение к сетям газо- или тепло- } \\
\text { снабжения, водоснабжения, во- } \\
\text { доотведения }\end{array}$ \\
\hline $\begin{array}{l}\text { Основные ста- } \\
\text { тьи дохода } \\
\text { управляющей } \\
\text { компании }\end{array}$ & $\begin{array}{l}\text { Сдача земельных участков, по- } \\
\text { мещений в аренду, оказание } \\
\text { коммунальных услуг, сдача в } \\
\text { аренду оборудования коллектив- } \\
\text { ного пользования, оказание спе- } \\
\text { циализированных услуг }\end{array}$ & $\begin{array}{l}\text { Сдача земельных участков, по- } \\
\text { мещений в аренду, оказание } \\
\text { коммунальных услуг }\end{array}$ \\
\hline
\end{tabular}


И. Ю. Унгаева, Н. Э. Шабыкова. Формирование региональной промышленной инфраструктуры как фактор развития производственного предпринимательства

Как видно, между этими понятиями есть общие характеристики и отличительные особенности. Общие характеристики заключаются в том, что технопарк и промышленный парк - это территории, на которых локализуют свое производство субъекты малого бизнеса разной деятельности. Предприятия - резиденты - могут пользоваться различными сервисными услугами, предоставляемыми управляющими компаниями парков (охрана, эксплуатация объектов общей инфраструктуры, инжиниринг и другие). Управление имущественным комплексом промышленного парка и технопарка осуществляется управляющей компанией.

Отличия этих территориальных зон состоят в их назначении: промышленные парки ориентированы на развитие промышленных производств, а технопарки на развитие наукоемких и высокотехнологичных производств. На площадке промышленного парка ведут производственную деятельность предприятия различных отраслей промышленности, не зависящих друг от друга. Имущественный комплекс промышленного парка располагается на большой территории и должен иметь развитую для эффективной деятельности резидентов инфраструктуру (транспортную, складскую, коммунальную, социально-бытовую, офисную). Основная цель технопарка - формирование инноваторов для создания высокотехнологичных производств. Для этого у технопарка должна быть развита бизнесинфраструктура (бухгалтерские, финансовые, юридические, консалтинговые услуги).

Роль таких территориальных зон в создании и развитии новых производств в регионах имеет важное значение. В связи с этим актуальными являются вопросы государственной поддержки создания таких производственных площадок. В качестве возможных направлений государственного финансирования можно выделить:

- строительство новых или реконструкция существующих производственных зданий;

- подведение и подключение энергетических и коммунальных коммуникаций;

- оснащение производственным оборудованием для коллективного использования резидентами.

Важное значение для деятельности управляющих компаний технопарков и промышленных парков, а также их резидентов являются налоговые льготы по региональным и местным налогам (налог на прибыль, налог на имущество, налог на землю), а также льготные арендные ставки в государственных парках и технопарках.

Одним из сдерживающих факторов развития малого предпринимательства в промышленности является недостаток готовых производственных площадок в Республике Бурятия. По данным Бурятстата, в 2019 г. в республике вели экономическую деятельность 854 малых и микропредприятия, или 7,4\% общей численности малых и микропредприятий. Количество индивидуальных предпринимателей в обрабатывающей промышленности республики в 2019 г. составило 1356 единиц, или $6,5 \%$ общей численности индивидуальных предпринимателей ${ }^{1}$.

${ }^{1}$ Статистический ежегодник. 2020. Статистический сборник / Бурятстат. Улан-Удэ, 2020. C. 301-304. 
Как отмечалось, в республике в настоящее время две действующие промышленные площадки: промышленный парк Республики Бурятия в г. Улан-Удэ и промышленный технопарк в пос. Каменск Кабанского района. В то же время у действующих предприятий имеются в наличии резервы неиспользуемых производственных площадей, которые могли бы найти применение при создании частных промышленных парков и технопарков.

\section{Литература}

1. Багинова В. М., Беломестнов В. Г. Потенциал развития малого промышленного предпринимательства в регионе // Известия Иркутской государственной экономической академии. 2015. Т. 25, № 6. С. 999-1003. Текст: непосредственный.

2. Технопарки стран мира: организация деятельности и сравнение / под редакцией В. А. Бариновой. Москва: Дело, 2012. 182 с. Текст: непосредственный.

3. Миронов Д. С., Плахин А. Е. Развитие технологических парковых структур как фактор повышения эффективности инновационного предпринимательства в Российской Федерации // Baikal Research Journal. 2016. T. 7, № 3. URL: http://brj-bguep.ru/reader/ article.aspx?id=20777 (дата обращения: 29.03.2021). Текст: электронный.

Статья поступила в редакциюю 19.14.2021; одобрена после рецензирования 28.04.2021; принята к публикациии 28.04.2021.

\section{DEVELOPMENT OF REGIONAL INDUSTRIAL INFRASTRUCTURE AS A GROWTH DRIVER FOR INDUSTRIAL ENTREPRENEURSHIP}

Inna Yu. Ungaeva

Cand. Sci. (Econ.), A/Prof.

inna120175@mail.ru

Natalya E. Shabykova

Cand. Sci. (Econ.), A/Prof.

shab-natalya@list.ru

East-Siberian State University of Technology and Management 40v Klyuchevskaya St., Ulan-Ude 670013, Russia

Abstract. Development of industrial infrastructure involving industrial and technology parks is a priority of regional industrial policy. The article discusses the trends in development of technology and industrial parks. We have considered the experience of creating technology parks under higher educational institutions of Russia as a scientific and technological base for the implementation of innovative projects. Based on the analysis of the current legislation on creation of technology parks by state authorities we have presented the types of technology parks in the Russian Federation. The article considers the state efforts aimed at creation of technology parks and models of their development - innovative, university and industrial. We also have studied the distinctive features of industrial parks and technology parks. The article analyzes the measures of state support for creation of technology parks and their role in the development of the regional economy, as well as the availability of industrial infrastructure for the needs of small business in the Republic of Buryatia.

Keywords: industrial park, technology park, industrial infrastructure, managing company, resident of technology park, micro-entrepreneurship, small business, regional industrial policy 
И. Ю. Унгаева, Н. Э. Шабыкова. Формирование региональной промышленной инфраструктуры как фактор развития производственного предпринимательства

For citation

Ungaeva I. Yu., Shabykova N. E. Development of Regional Industrial Infrastructure as a Growth Driver for Industrial Entrepreneurship. Bulletin of Buryat State University. Economy and Management. 2021; 2: 83-89 (In Russ.).

The article was submitted 19.04.2021; approved after reviewing 28.04.2021; accepted for publication 28.04.2021. 